Ann. Biol. anim. Bioch. Biophys., 1978, 18 (4), 843-850.

\title{
Use of immunofluorescence for localization of somatostatin-like antigen in the rainbow trout (Salmo gairdneri). Comparative distribution of LH-RF and neurophysin
}

\author{
par M. P. DUBOIS, R. BILLARD *, B. BRETON * \\ Station de Physiologie de la Reproduction, I. N. R. A., \\ Nouzilly, 37380 Monnaie, France \\ * Laboratoire de Physiologie des Poissons, I. N. R. A., \\ 78350 jouy en Josas, France.
}

\begin{abstract}
Summary. A somatostatin-like antigen has been localized in the brain and the digestive tract of the rainbow trout. In the brain, SRIF perikarya were observed scattered throughout the hypothalamus or present in definite hypothalamic nuclei (i) nearly all the Gomori negative perikarya of the NPP (Peter and Gill, 1975) appeared to react with anti-SRIF but not at all with anti-neurophysin (ii) a small unidentified nucleus was present in the dorsomedial hypothalamus and showed a few SRIF-containing perikarya (iii) many SRIF cells were scattered in the rostral and median peri-infundibular areas of the NLT (iv) in the wall of the 3rd ventricle, hypendymocytes next to the upper part of the NPO did not react uniformly to anti-SRIF. Axonal endings containing SRIF, LH-RF and neurophysin followed the digitations of the pars nervosa that enter the adenohypophysis. LH-RF and SRIF fibers followed the same routes and terminated only in the mesoadenohypophysis ; neurophysin fibers end only in the meta-adenohypophysis. At the periphery, SRIF cells were observed in Langerhans islets of the endocrine pancreas and in the mucosa of the gastro-duodenal duct.
\end{abstract}

Abbreviations used : LH-RF : Luteinizing Hormone-Releasing Factor ; SRIF : Somathormone Release Inhibiting Factor ; TSH-RF : Thyroid Stimulating Hormone-Releasing Factor ; NPO : Nucleus Preopticus ; NLT : Nucleus Lateral Tuberis ; NPP : Nucleus Preoplicus Periventricularis.

\section{Introduction.}

If somathormone release inhibiting factor (SRIF) does not directly control the gonadotropic hormones release in mammals (Besser ef al., 1974 ; Wale ef al., 1975), it interferes in the physiology of their reproduction by the way of prolactin (Davis, 1975 ; Davis and Anfinson, 1975), this hormone operating on the LH-RF release as reviewed by Leonardelli (1977).

In this prospect, we tried to determine in this report immunofluorescent localization of hypothalamic centers the cells of which synthesize SRIF. Results on the rainbow trout are presented. 

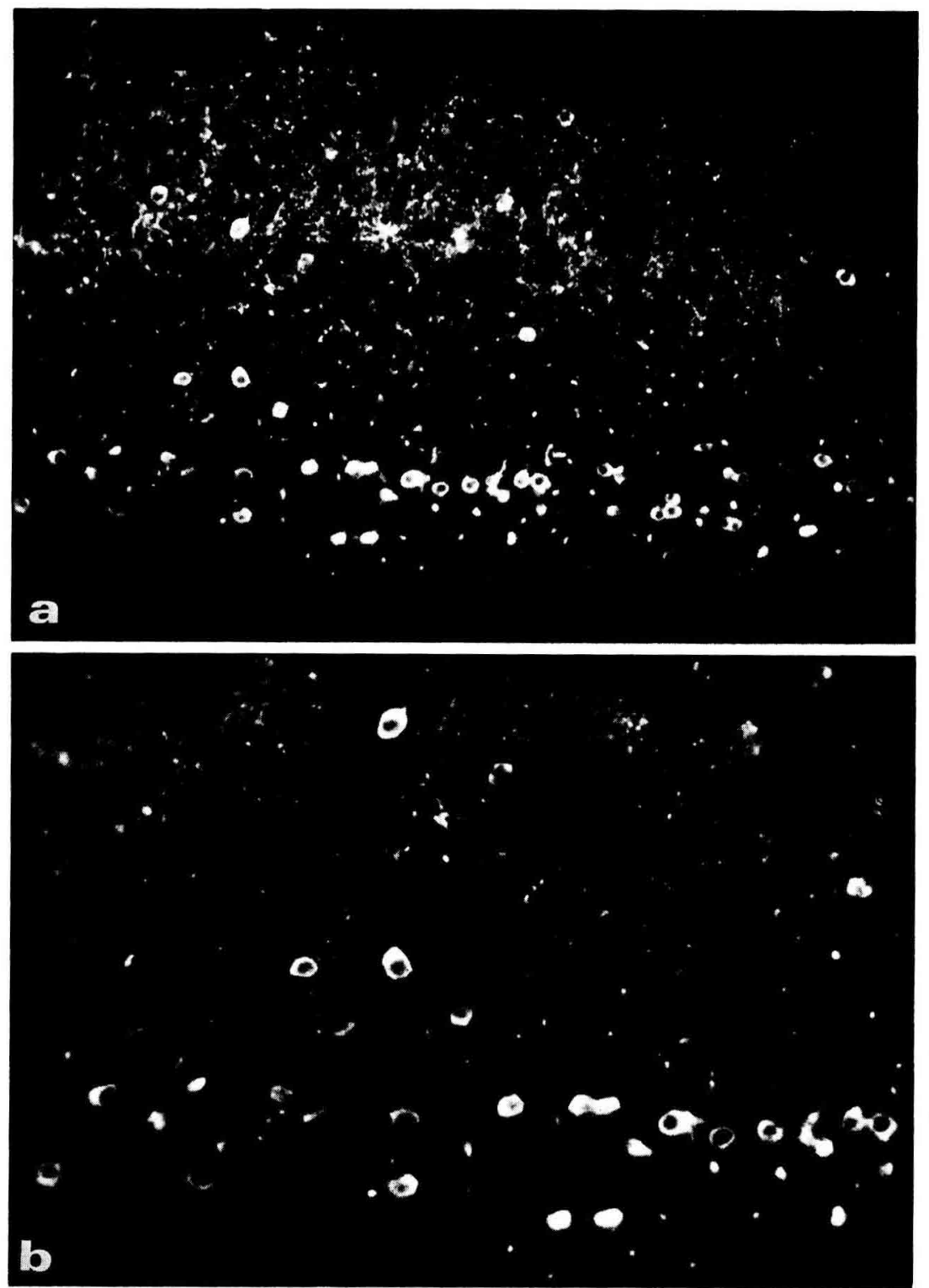

FIG. 1. - Trout brain. Parasagittal section close to the symmetric plane of the brain showing the median peri-infundibular area in the hypothalamus. a) SRIF immunoreactive cells scattered among nonreacting parvocellular perikarya of the NLT. Af its periphery, a dense network of SRIF fibers surrounds the periventricular grey substance. $\times 175, b$ ) The same field showing immunoreactive perikarya at a higher magnification. $\times 175$. 

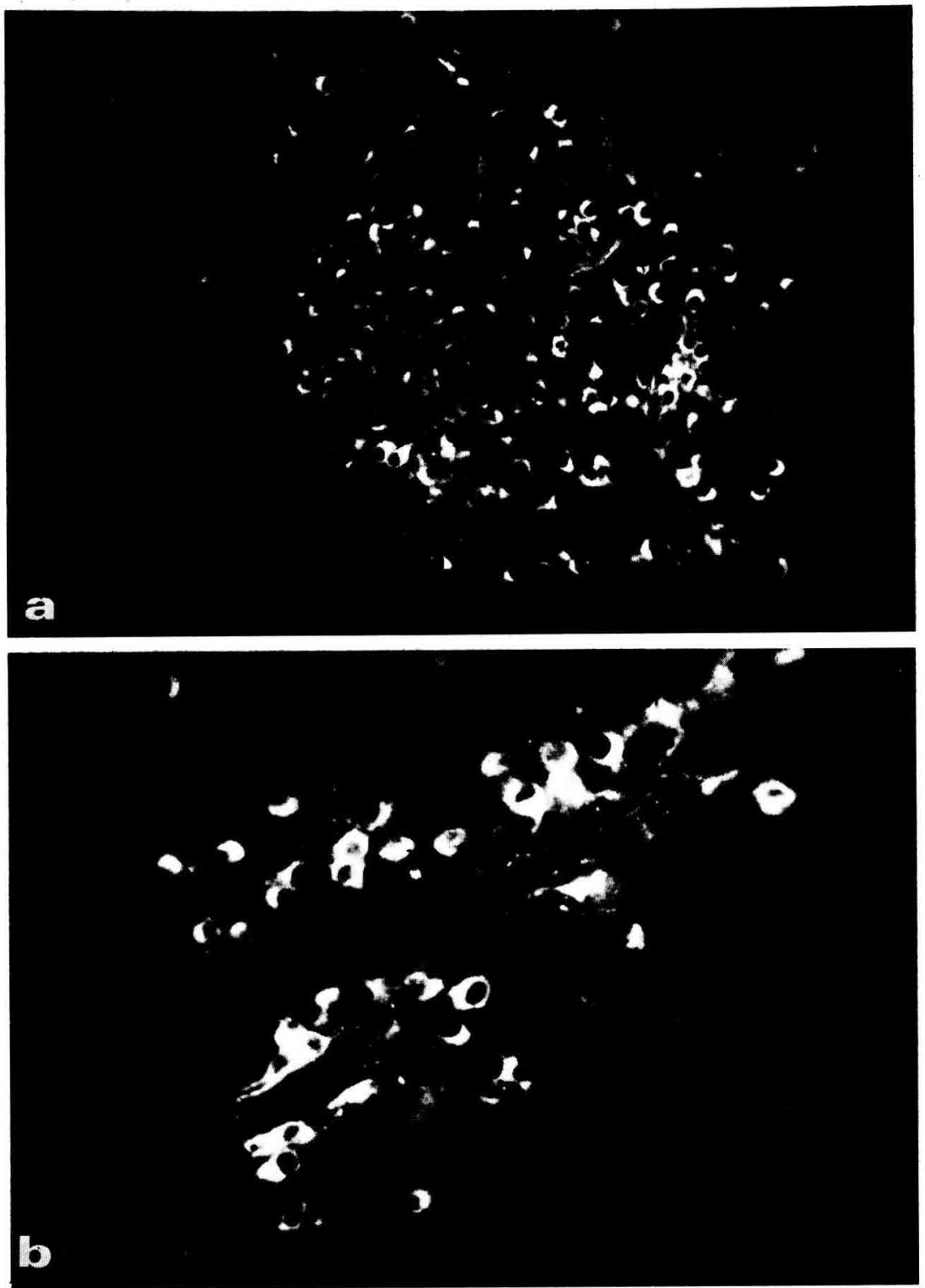

FIG. 2. - Trout brain. More lateral parasagitfal section than the former. Hypothalamic suprachiasmatic area. NPP (Peter and Gill, 1975). a) Many immunofluorescent perikarya reacting with SRIF seen at a low magnification. $\times 175 . b)$ Detail of a field at the periphery of the NPP seen at a higher magnification. $\times 300$. 


\section{Material and methods.}

Brain and other tissue samples were obtained from adult male or female rainbow trouts killed at different times of the year. They were fixed with Bouin-Holland and embedded in paraffin. Rehydrated sections of $5 \mu$ thickness were studied by immunofluorescence using the indirect method and a counter stain of 0.01 p. 100 Evans Blue. The preparation and specificity of rabbit anti-sera used (anti-SRIF, anti-LH-RF, antibovine neurophysin) have been reported previouly (Dubois, 1975 ; Dubois, 1976a ; 1976 b et 1978 ; Leonardelli ef al., 1973 ; Dubois and Barry, 1974).

\section{Results.}

Encephalic localization of SRIF immunoreactive perikarya and axonal endings.

Perikarya. - Perikarya appear isolated and scattered throughout the hypothalamus, grouped in well-individualized hypothalamic nuclei, or scattered over the periventricular grey nucleus lateral fuberis (NLT) substance. They are small uni- or bipolar neurons ; their nucleus $(10$ to $12 \mu \varnothing)$ is surrounded by a thin halo of immunoreactive cytoplasm.

In the suprachiasmatic area in front of the hypothalamus, two well-condensed symmetric nuclei surround the supra optic recess of the 3 rd ventricle at the periphery of the rostral end of each nucleus preopticus (NPO) (fig. 2). This is well demonstrated using an anti-bovine neurophysin antiserum. The nuclei are well separated from the NPO, and do not react with anti-neurophysin. According to the nomenclature of Peter and Gill (1975), they would correspond to the Gomori negative nucleus preopticus periventricularis (NPP), distinct from Gomori positive NPO.

Two symmetric cell groups containing a few cells appear in the dorsomedial hypothalamus at a distance from the wall of the 3 rd ventricle. They have not been related to well-defined nuclei.

Many immunoreactive cells are scattered in the NLT, close to the ventricular cavity in the rostral and the median peri-infundibular areas (fig. 1). A dense network of SRIF immunoreactive fibers surrounds the periventricular grey substance when their perikarya are present.

Many SRIF immunoreactive hypendymocytes may be seen at times next to the upper part of the NPO.

Axonal endings. - The axons end in the pituitary. Their dense network is observed in the digitations of the pars nervosa only distributed in the mesoadenohypophysis (fig. 3). The LH-RF immunoreactive fibers follow the same route (fig. 4); they are very scarce, while axonal endings reacting with anti-neurophysin are only seen in the ramifications of the pars nervosa distributed in the meta-adenohypophysis.

Peripheric localization of SRIF cells.

As seen in other classes of vertebrates, SRIF cells are observed in the Langerhans islets of the endocrine pancreas; they are already numerous in the 1-day old hatched 

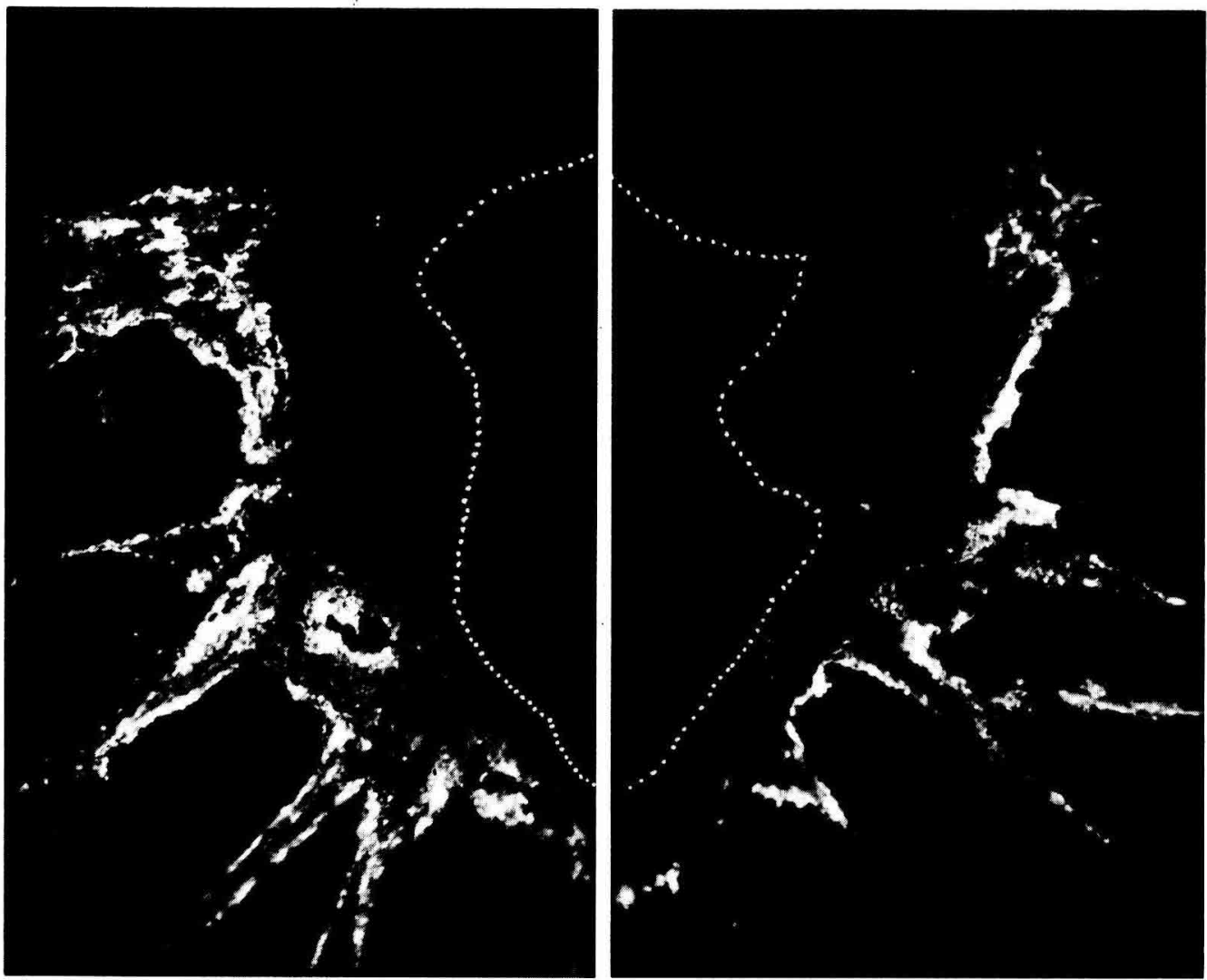

FIG. 3. - Trout brain. Cross-section in a plane perpendicular to the sagittal axis of the brain. Infundibulum and pituitary (pars nervosa). SRIF immunoreactive fibers are distributed only in the symmetric ramifications of the pars nervosa entering the mesoadenohypophysis. Dotted line shows the limit of the infundibulum. $\times 175$.

trout. These cells are aiso present in the anterior part of the gastro-intestinal duct where they are scattered in the digestive mucosa.

\section{Discussion.}

The immunocytological pattern of the hypothalamic centers systematized above appears to differ, depending on the various physiological conditions of the individuals investigated at different times of the year. Therefore, to obtain a representative picture of SRIF cell distribution, we had to include all the observations made during the year, not taking into account the physiological state of the individuals. Particular aspects of these different centers in relation to definite physiological or experimental situations will be reported later. 

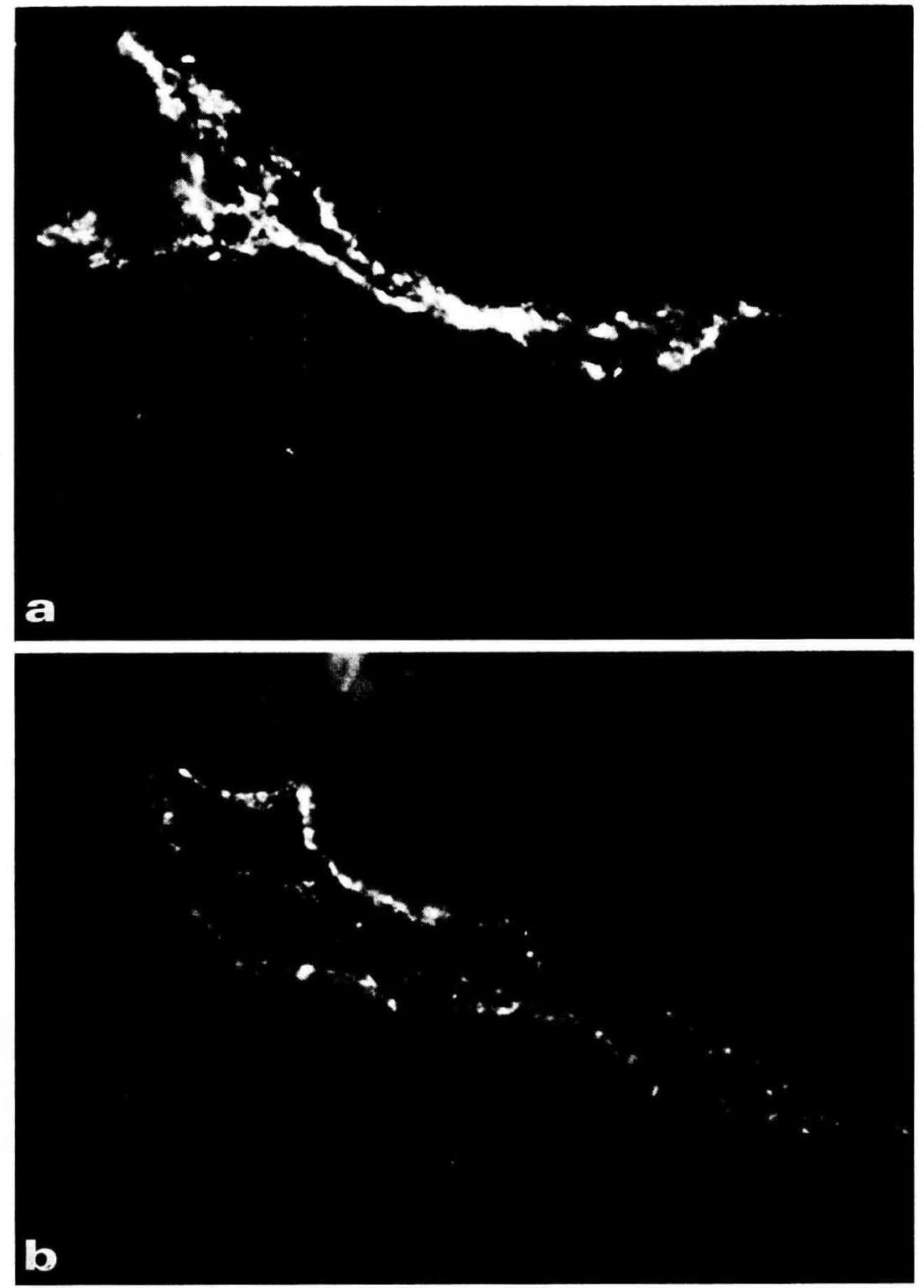

FIG. 4. - Trouf brain. Pituitary. Comparative distribution of SRIF and LH-RF immunoreactive axons in the ramifications of the pars nervosa that enter the mesoadenohypophysis showing SRIF and LH-RF flbers following the same route. a) SRIF fibers, b) LH-RF fibers. $\times 450$. 
The number of SRIF cells, the intensity of their immunofluorescent reaction, and the size of given immunoreactive cell groups appear to vary considerably depending on the physiological state of the individuals. These variations are unrelated to the intensity of the reaction observed in axonal endings. This discrepancy confirms the hypothesis postulating the rarity (or absence) of immunoreactive neurosecretory cells observed in vertebrates in various physiological siates. This paucity might be essentially due to a too low concentration of the neuropeptide in those cells, which would be the result of either a high axonic flow, low-level SRIF synthesis, or both these factors (Dubois, in press).

Peter and Gill (1975) separated the NPP from the NPO according to the difference observed with paraldehyde Fuchsin staining. This distinction agrees with the presence of neurophysin in the NPO and its absence in the NPP.

In the adult trout, hypendymal cells reacting with anti-SRIF are observed in undefined conditions. Such hypendymocytes have been continuously seen in mammalian fetus (Dubois, 1976a ; 1976b, 1978).

Symposium sur la Reproduction des Poissons Paimpont, France, 19-21 septembre 1977.

Acknowledgments. - The authors are indebted to Dr. R. Guillemin, The Salk Institute, San Diego, California for his kind gifts of SRIF ; to Dr. Stutinsky, Institut de Physiologie, Strasbourg, France for his allotment of neurophysin and to Dr. R. E. Peter, Department of Zoology, University of Alberta, Canada, for his careful revision of the English manuscript. Thanks are due to Mrs. Chantal Couvrand, Nadine Martinat and $\mathrm{Mr}$. M. Teriot for their valuable histological, immunochemical and photographic assistance. This work was partly supported by a NATO grant (No 1035).

Résumé. Un antigène « somatosłatine-like » a été localisé dans le cerveau et le tractus digestif de la truite Arc-en-ciel. Dans le cerveau, les péricaryons SRIF+ sont épars dans l'hypothalamus ou localisés dans des noyaux hypothalamiques bien définis : $i$ ) presque tous les péricaryons Gomori négatifs du NPP réagissent avec l'anti-SRIF ; ii) un petit noyau non identifié dans l'hypothalamus dorso-median présente quelques péricaryons contenant du SRIF ; iii) de nombreuses cellules à SRIF+ apparaissent éparses dans les aires péri-infundibulaires médianes et rostrales du NLT ; iv) dans la paroi du $3^{e}$ ventricule, les hypendymocytes près de la partie supérieure du NPO ne réagissent pas uniformément à l'anti-SRIF. Les terminaisons axonales contenant du SRIF, du LH-RF et de la neurophysine suivent les digitations de la pars nervosa qui pénètrent dans l'adénohypophyse. Les fibres LH-RH et SRIF+ se terminent seulement dans la mésoadénohypophyse, tandis que les fibres à neurophysine se terminent seulement dans la métaadénohypophyse. A la périphérie, des cellules SRIF+ sont observées dans les îlots de Langerhans du pancréas endocrine et dans la muqueuse du conduit gastro-duodénal.

\section{References}

BESSER G. M., MORTIMER C. H., CARR D., SCHALLY A. V., COY D. H., EVERED D., KASTIN A. J., TURNBRIDGE W. M. G., THORNER M. D., HALL R., 1974, cifed by VALE W., ef al., 1975.

DAVIS S. L., 1975. Somatostatin : its influence on plasma levels of growth hormone, prolactin and thyrotropin in sheep. J. Anim. Sci., 40, 911-916. 
DAVIS S. L., ANFINSON M., 1975. Sole response influence of prostaglandin $E_{1}$ and SRIF on plasma levels of growth hormone, prolactin and thyrotropin in sheep. J. Anim. Sci., 41, 172-177.

DUBOIS M. P., 1975. Presence of immunoreactive somatostatin in discrefe cells of the endocrine pancreas. Proc. nat. Acad. Sci. U. S. A., 72, 1340-1343.

DUBOIS M. P., 1976a. Mise en évidence par immunofluorescence d'un décapeptide, le LH-RF dans l'éminence médiane. Ann. Hisfoch., 21, 269-278.

DUBOIS M. P., 1976b. Le système à somatostatine. Rôle essentiel des tanycytes. In Les actions thémafiques de l'INSERM, Rapport $n^{\circ}$ 7, Neuroendocrinologie, 65, 179-190, INSERM, Paris.

DUBOIS M. P., 1978. Differentiation of immunoreactive neurosecretory cells. A review. In La Biologie cellulaire des processus neurosécrétoires hypothalamiques (Bordeaux, 6-10 sept. 1977), CNRS éd. (to be published).

DUBOIS M. P., BARRY J., 1974. Répartition comparée de trois neurofacteurs hypothalamiques LHRF, SRIF et neurophysine dans l'hypothalamus et l'éminence médiane : étude en immunofluorescence. Ann. Endocrin. (Paris), 35, 663-664.

LEONARDELLI J., 1977. Modification des neurones hypothalamiques à LH-RH après injection intraveineuse de prolactine chez le cobaye. Ann. Endocrin. (Paris), 38, 235-242.

LEONARDELLI J., BARRY J., DUBOIS M. P., 1973. Mise en évidence par immunofluorescence d'un constituant immunologiquement apparenté au LH-RF dans l'hy.pothalamus et l'éminence médiane chez les mammifères. C. R. Acad. Sci. Paris, Série D, 276, 2043-2046.

PETER R. E., GILL V. E., 1975. Stereotaxic atlas and technique for forebrains nuclei of the goldfish, Carassuis auratus. J. compar. Neur., 159, 69-102.

VALE W., BRAZEAU P., RIVIER C., BROWN M., BOSS B., RIVIER J., BURGUS R., LING N., GUILLEMIN R., 1975. Somatostatin. Rec. Progr. Hormone Res., 31, 365-397. 